\title{
Attacks on United Nations Peacekeeping Forces: A Violation of International Humanitarian Law
}

Tania Gicela Bolaños*

\begin{abstract}
This paper raises the question as to whether the United Nations peacekeeping forces could be awarded a civilian status during the armed conflict in which they are deployed; which is important for the determination of prohibition of attacks against them. The paper is based on the premise that distinction between civilians and combatants is crucial under international humanitarian law. In doing so, this paper briefly analyses the nature of UN peacekeeping operations and the qualification of the UN forces' members as civilians or combatants. It also delves into the emerging category of UN robust peacekeeping operations to ascertain whether its personnel would be treated as civilians or combatants in the context of an international armed conflict.
\end{abstract}

Keywords: Direct Participation in Hostilities, International Humanitarian Law, Peace Enforcement Operations, Robust Peacekeeping Forces, UN Peacekeeping Operations.

* Attorney of Law (Colombia), LLM and PhD at the Heidelberg University (Germany), guest researcher at the Max Planck Institute for Comparative Public Law and International Law, visiting professional attorney at the Interamerican Court of Human Rights, Former Law School Dean, currently Director of the Universidad Cooperativa de Colombia Sede Pasto (Colombia); taniagicela@hotmail.com, tania.bolanos@ucc.edu.co The author would like to express her gratitude to Marc Schlagenhoff for critical comments on the earlier drafts. 


\section{Introduction}

The complex combination of international and internal elements, the methods and weapons employed by the belligerents, the goals of the fighters, and the nature of the parties involved transform the classical internal armed conflict into one potentially threatening the international peace and security of the neighbouring states. In order to maintain and restore international peace and security as well as peace in the region, the international community has authorized the Security Council of the United Nations to determine the measures that are to be taken to prevent an aggravation of the situation. The Security Council can make use of the peaceful settlement of disputes according to Chapter VI of the UN Charter, or it can take coercive measures under Chapter VII, either involving use of armed force or not subject to the determination of the existence of any threat to peace, breach of peace, or act of aggression. Over the period of time, many UN peace operations have been deployed in international and internal armed conflicts, both as peacekeeping ${ }^{1}$ and as peace enforcement ${ }^{2}$ operations. The former permits the use of force only in self defence. The peacekeepers are considered civilians and enjoy special protection from armed attacks. In contrast, the peace enforcers may use armed force beyond self defence, which means that peace enforcers are allowed to engage in combats and therefore are legitimate military targets. This separation between peacekeeping and peace enforcement operations is not so clear in reality. In the recent times, most of the UN peace operations are neither peacekeeping nor peace enforcement, but a mixture of both, known as robust peacekeeping operations. This situation creates difficulty in determining a legitimate military target and in ascertaining as to

${ }^{1}$ (E.g. UNOSOM I in Somalia and UNAMIR I, as well as AMIS in Sudan). 2 (E.g. ONUC, IEMF and the United Nations Force Intervations Brigade FIB in the Democratic Republic of Congo; UNITAF, UNOSOM II in Somalia (at the begining); the Turquise Operation in Ruanda; ECOMOG in Sierra Leone and UNMIS in Darfur). 
whether protection as per International Humanitarian Law (IHL) is afforded to the peace operations or not. ${ }^{3}$

The aim of this paper is to put forward thoughts on determining the real nature of the robust peacekeeping operations' soldiers and to contribute to solving the questions related to their protection. Consequently, the first part of this paper presents the factual background regarding the deployment of UN peace operations. The second part portrays the various types of UN peace operations, including the robust peacekeeping operations as a special case among the traditional two. The third part analyses the possibility of the UN forces being engaged in hostilities as combatants, therefore becoming legitimate military targets according to IHL.

\section{UN Peacekeeping Operations: Factual Background}

The United Nations (UN) is an organisation created to save succeeding generations from the scourge of war. ${ }^{4}$ It is the principal institution for building, consolidating and exercising the authority of the international community, in order to fulfil the principles and purposes of the UN Charter, by endowing its decisions with legitimacy. The first and foremost obligation of the UN is to protect peace and security, as well as to promote international cooperation, in order to solve, among other things, problems of social, economic and humanitarian nature and to encourage the respect for human rights and fundamental freedoms on a global scale. ${ }^{5}$

Each UN member is obliged to protect the welfare of its own people and meet its obligations to the wider international community. ${ }^{6}$ However when a state does not or cannot fulfil this obligation, the international community needs to compensate for this failure by offering the required assistance through the UN. In case of acts of aggression, breach of peace, internal armed conflicts,

3 (E.g. MONUC and MONUSCO in Congo, UNOSOM II in Somalia, UNAMIR I and II in Rwanda, UNAMSIL in Sierra Leone, UNMIS and UNAMID in Darfur).

${ }^{4}$ Charter of the United Nations, Preamble.

${ }^{5}$ Charter of the United Nations art. 1, Oct. 24, 1945, 1 UNTS XVI.

6 U.N. Doc. A/59/565 (2004), ๆ 29. 
or of serious violations of human rights, representing a threat to international peace, the UN can decide through the Security Council on the measures that shall be taken to maintain or restore peace and security; by the activation of the collective security system established in Chapter VI and VII of the UN Charter, together with Chapter VIII where the participation of regional organisations is required to execute the relevant resolutions. ${ }^{7}$

The Safety Convention of the United Nations and Associated Personnel, 1994 provides that attacks against, or other mistreatment of personnel who act on behalf of the UN are unjustifiable and unacceptable, by whomsoever committed, and provides for the punishment of those who have committed such attacks8. Those who are personally involved in peacekeeping operations in accordance with the UN Charter are entitled to the protection given to civilians under the international law of armed conflicts and attacks on them are criminalized by International Criminal Law (ICL). ${ }^{9}$ However, not all military attacks against peace forces constitute a violation of the IHL; it depends on the UN mandate based on which the UN peace forces are deployed. The next section will portray the different types of UN peace operations that helps to determine the protection afforded to the UN peace forces.

7 Robert Cryer, The Security Council and Article 39: A Threat to Coherence?, 1(2) J CONFLICT SECURITY LAW 161, 161-62 (1996); Lothar Brock, Von der humanitären Intervention zur Responsibility to Protect: Kriegserfahrung und Völkerrechtsentwicklung seit dem Ende des Ost-West-Konflikts, in FREIHEIT, FESTSCHRIFT FUR MICHAEL BOTHE 19, 23 (A. Frischer-Lescano et al. Eds.., 2008); Fred Grünfeld, Human Rights Violations: A Threat to International Peace and Security, in THE ROLE OF THE NATION-STATE IN THE $21^{\text {st }}$ CENTURY, HUMAN RIGHTS, INTERNATIONAL ORGANISATIONS AND FOREIGN POLICY 427, 427 (M. Castermans-Holleman ed., 1998); INGER ÖSTERDAHL, THREAT TO THE PEACE: THE INTERPRETATION By THE SECURITY COUNCIL OF ARTICLE 39 OF THE UN CHARTER 26-7 (1998); Karel Wellens, The UN Security Council and New Threats to the Peace: Back to the Future, J CONFLICT SECURITY LAW 8, 15, 43-6 (2003); MiCHAEL E. BROWN, THE INTERNATIONAL DiMENSIONS OF CONFLICT 594 (M. Brown ed. MIT Press, 1996).

8 Convention on the Safety of United Nations and Associated Personnel art. 9, Dec. 09, 1994.

${ }^{9}$ The Rome Statute of the International Criminal Court art. 8, Jul. 17, 1998. 


\section{UN Peace Operations}

To ensure international peace and security, the UN makes use of UN peace operations whose mandate invokes measures under Chapter VI (peacekeeping) or stronger measures described under Chapter VII (peace enforcement of the UN Charter). Over the years, the protection of civilians during the armed conflicts has been an imperative of the UN peace forces, which has enforced the special protection guaranteed under IHL. Nevertheless, situations may arise where the Security Council does not take a clear decision to enforce peace, but goes beyond traditional peacekeeping (robust peacekeeping), thereby affecting the legal status of the personnnel involved in UN peace operations. The three types of mandate are discussed below.

\section{Peacekeeping Operations}

One of the most important measures of the UN for the peaceful settlement of disputes is the peacekeeping operation based on Chapter VI of the UN Charter. In its origin, they were used only in international armed conflicts. ${ }^{10}$ However, the non-international armed conflicts or the internationalized ones became more frequent. While the term peacekeeping does not appear in the UN Charter, it was thought to work to preserve peace, where fighting had been brought to a halt. ${ }^{11}$

The UN Secretary General defined peacekeeping operations as the "deployment of a United Nations presence in the field, hitherto with the consent of all the parties concerned, normally involving United Nations military and/or police personnel and frequently civilians as well. Peacekeeping is a technique that expands the possibilities for both the prevention of conflict and the making of peace (through such peaceful means as those foreseen in Chapter VI of the Charter of the United Nations)."12

10 Eno Robert Wundeh, United Nations Peacekeeping Operations and Respect for Human Rights, 24 SOUTH AFRICAN YEARBOOK OF INTERNATIONAL LAW 76 - 77 (1999).

11 UN Doc. A/47/277/ (1992), 915.

12 UN Doc. A/47/277 (1992), ๆ 20. 
Peacekeepers are lightly armed and their deployment does not imply the exercise of coercive military measures. Their deployment is based on the authorisation of the principal parties to the armed conflict and supported by their co-operation, the major principles governing them being self defence and impartiality. ${ }^{13}$ Their work is more akin to armed police than to standard combat. ${ }^{14}$ Hence, peacekeeping operations distinguish themselves from the others based on three principles that must persist: (a) establishment on the consent of the parties; (b) impartiality in functioning and (c) non use of force except in self defence. These principles were introduced by the UN Secretary General during the deployment of the first UN Peacekeeping Operation, the United Nations Emergency Force. 15

The traditional peacekeeping operations, as they are usually known, are composed of monitoring missions with unarmed personnel, and lightly armed military personnel, whose tasks differ from situation to situation, depending on the nature of the conflict and the specific set of challenges. Ordinarily, they are given responsibilities such as monitoring ceasefire, demilitarizing zones and facilitating the withdrawal of warring parties' troops. ${ }^{16}$ Whether the characteristics of the traditional peacekeeping operations are enough to entitle the peacekeepers for the protection

13 Nigel D. White, Keeping the Peace: The United NAtions and the MAINTENANCE OF INTERNATIONAL PEACE AND SECURITY (Manchester University Press, 3rd ed., 1997); United NATIONS, THE Blue Helmets - A ReView of United NATIONS PEACE - KeEPING (New York United Nations 3rd ed., 1996); Sally Morphet, UN Peacekeeping and Election - Montering, in UNITED NATIONS DiVIED WORLD 201 (Adam Roberts and Benedict Kingsbury ed., 2007); Shyla Vohra, Impartiality in United Nations PeaceKeeping, 9(1) LEIDEN JOURNAL OF INTERNATIONAL LAW 63, 76(1996).

${ }^{14}$ Eno Robert Wundeh, United Nations Peacekeeping Operations and Respect for Human Rights, 24 SOUTH AFRICAN YEARBOOK OF INTERNATIONAL LAW 76, 77 (1999).

15 UN Doc. A/3943 §127, Oct. 09, 1948.

16 United Nations Peacekeeping, Mandates and the legal basis for peacekeeping, UNITED NATION ORGANISATION, available at, http://www.un.org/en/peacekeeping/operations/pkmandates.shtml (last visited on May 18, 2015). 
given to civilians under IHL in order to criminalize attacks on them will be analysed later in this article.

\section{Peace Enforcement Operations}

In order to restore international peace and security, the UN Charter encompasses in Chapter VII coercive measures, which involves the use of military force. ${ }^{17}$ The Security Council is the only authorised organ of the UN to order these measures prior to the determination of the existence of any threat to peace, breach of peace, or acts of aggression. ${ }^{18}$

Peace enforcement operations are UN peace operations to maintain or restore international peace and security through the use, or the threat to use of military force. ${ }^{19}$ Coercive action is employed to enforce a ceasefire, to ensure compliance with the resolutions imposed by the Security Council, the IHL, and the human rights. The Security Council may utilize regional organizations and agencies for enforcement action under its authority and in accordance with the UN Charter.

17 Mohamed A. Osman, The United Nations And PeAce EnForcement: WARS, TERRORISM AND DEMOCRACY 52-53 (Ashgate Publishing, 2002); John Quigley, The "privatization" of Security Council Enforcement Action: a Threat to Multilateralism, 17 MichigAN JIL 249, 262 (1996); TREVOR FINDLAY, THE UsE of Force IN UN PEACE OPERATIONS 376 (Sipri \& Oxford University Press, 2002).

18 Charter of the United Nations art. 39, Oct. 24, 1945, 1 UNTS XVI.

19 United Nations Peacekeeping, Principles and Guidelines, UNITED NATIONS ORGANISATION, available at http://www.un.org/en/peacekeeping/operations/principles.shtml (last visited on May 19, 2015); Headquarters Department of the Army, US Army's Field Manual - FM 100-23 Peace Operations, CENTRE FOR DISASTER MANGAEMENT AND HUMANITARIAN ASSISTANCE, available at http:/ / www.globalsecurity.org/military/library/policy/army/fm/10023/index.html (last visited on May 12, 2015); Headquarters Department of the Army, Peace Operations Multi-service tactics, Techniques, and Procedures for Conducting Peace Operations, BITS, (Oct. 26, 2003) http://www.globalsecurity.org/military/library/policy/army/fm/3-0731/fm3_07x31.pdf. 
The mandate of the peace enforcement operations involves attacks, conducted inter alia to maintain and restore public security and order, to protect the delivery of humanitarian relief and to improve the humanitarian situation on the field, to monitor protected zones and important infrastructure of the country and to ensure both the forcible separation of belligerent parties and the definitive withdrawal of foreign military supporters of the armed conflict. Further, the mandate can also encompass the prevention of a civil war or other armed conflicts between the parties and improvement of security on the field.

Since these kinds of UN operations are based on Chapter VII of the UN Charter, neither the authorisation of the legitimate government of the host state nor of any of the parties of the armed conflict is required for their deployment. They can be deployed even against the will of the belligerent parties ${ }^{20}$ and impartiality is not a requirement.

\section{Robust Peacekeeping Operations}

Given the nature and challenges of some armed conflicts, lightly armed soldiers may not be enough to maintain or restore peace. The use of military force is therefore required, ${ }^{21}$ although the

20 Hugo Slim, Military Humanitarianism and the New Peacekeeping: An Agenda forPeace? THE Journal OF HumanitARIAN Assistance, (Sep. 22, 1995), https://sites.tufts.edu/jha/archives/64; Jane Boulden, Peace Enforcement: The United Nations Experience in Congo, Somalia, and Bosnia, 1 POLITICAL SCIENCE QUARTERLY 117, 163 (2013); Jit Rikhye, Sovereignty and International Intervention in the Internal Affairs of States: Peacekeeping Operations, in THE DUMBARTON OAKS CONVERSATIONS AND THE UNITED NATIONS 73 (Ernest R. May and Angeliki E. Laiou eds., 1998); Nicholas Tsagourias, Consent, Neutrality/Impartiality and the Use of Force in Peacekeeping: their constitutional dimension, 11 JOURNAL OF CONFLICT AND SECURITY LAW 465, 469 (2006); George F. Oliver, The Other Side of Peacekeeping: peace enforcement and who should do it?, 8 INTL. PEACEKEEPING: THE YEARBOOK OF INTL PEACE OPERATIONS 102 (2004).

21 Annan K, Statement by the United Nations Secretary-General Before the special commemorative meeting of the general assemby honouring 50 years of peacekeeping, INTERNATIONAL PEACEKEEPING, (Oct. 06, 1998), http://www.un.org/Depts/DPKO/pk5060sg.htm; Geroge F Oliver, The Other Side of Peacekeeping: Peace Enforcement and Who Should Do It?, 8 
Security Council does not use the provisions of Chapter VII of the UN Charter to enforce peace, but to ensure the compliance with the mandate of the peacekeeping operation. While conducting the operations to maintain peace, they are granted more powers than the traditional peacekeeping operations and by their nature belong to the coercive measures under Chapter VII. However, they do not become peace enforcement operations. ${ }^{22}$ This new sort of peace operations combines elements of the peacekeeping operations under Chapter VI with the use of force under Chapter VII of the UN Charter. They are generally known as peace operations of third generation and constitute the most frequent UN peacekeeping operations in the present times.

The three basic principles that characterize a peacekeeping operation should be featured in a robust peacekeeping operation, although with some variations given the UN Mandate and the use of coercive measures. The basic principles are (a) establishment with the consent of the main parties; (b) impartiality in functioning; (c) non use of force except in self defence in a broad sense. ${ }^{23}$

Owing to the express reference to Chapter VII of the UN Charter, robust peacekeeping operations are allowed to use 'the necessary means' in order to fulfil the mandate given by the UN Security Council. The distinctive feature of these UN peace operations is the mandate, which emphasises on the protection and defence of specific persons and places, within the broad ambit of self defence.24 The notion of self defence in such broad sense encompasses the protection and defence of peacekeepers, UN

Intl. Peacekeeping: The YearboOK of Intl Peace Operations 101, 109 (2002); KAREN MingST \& MARGARET KARNS, THE United NATIONS IN THE POST-COLD WAR ERA 82 (Boulder, WestviewPress, 1995 2nd ed., 2000).

22 N., Tsagourias, Consent, Neutrality/ Impartiality and the Use of Force in Peacekeeping: Their Constitutional Dimension, 11(3) J.C.S.L., 472 (2006).

${ }^{23}$ Speical Research Report, Special Research Report No. 1: Security Council Action Under Chapter VII: Myths and Realities, SECURITY COUNCIL REPORT, (Jun. 23, 2008), http://www.securitycouncilreport.org/special-researchreport/lookup-c-glKWLeMTIsG-b-4202671.php.

24 U.N. Doc., A/55/305-S/2000/809 (2000); U.N. Doc., A/57/767 (2003) 4, I 26. 
installations, as well as ensuring the freedom of movement of peace keepers; affording protection to civilians under imminent threat, to personnel of nongovernmental organizations, to the most important locations and buildings of the country and to persons with protected status such as refugees, internally displaced persons, children, women and political leaders. This plethora of tasks exposes the peacekeepers to a high risk of accidental injury or of deliberate attack.

Unlike peacekeeping operations, the authorisation to use force within the broad sense of self defence does allow the deployment of offensive or active military activities, ${ }^{25}$ which might achieve better results in maintaining the peace. These attributions justify the designation as robust peacekeeping operation. The consent of all involved parties or of the legitimate government will be sought before the deployment of the robust peacekeeping operation. Nevertheless their refusal does not hinder the UN mission. In order to determine whether there is some difference between the protection awarded to the UN peace forces of traditional peacekeeping, robust peacekeeping and peace enforcement operations, the next section of the article will analyse their participation in the hostilities.

\section{Legal Protection of the UN Peacekeeping Forces}

The UN does not have an army to maintain or restore the peace; it has to make use of either the army of the UN members or the army of regional organizations who for the purpose of establishing the legal status of the UN peace forces are classified in the same functional way. The legal protection accorded to the personnel of UN peace operations has civil and criminal dimensions. The scope

25 N.D. White, Keeping the Peace, THE UNITED NATIONS AND THE MAINTENANCE OF PEACE AND SECURITY, 228-9 (Manchester Univ Press; 2 Sub edition 1998); Ove Bring, Peacekeeping and Peacemaking: prospective issues for the United Nations, 20 MULR 55, 60-1 (1995); David N. Gibbs, The United Nations, International Peacekeeping and the Question of "impartiality": revisiting the Congo Operation of 1960, 38 J MOD AFR STUD 259, 360 (2000); (Some Examples are: MONUC in Congo; UNOSOM II in Somalia; UNAMIR in Rwanda; UNPROFOR in Bosnia). 
of this article, however, is limited to discussing the protection against armed attacks.

Although UN peace forces are engaged in armed conflicts, the primary source of authority is not IHL, but the specific mandate for that peace operation, issued by the Security Council or other (e.g. regional) executive body and the Rules of Engagement. ${ }^{26}$ Until the Safety of Personnel Convention 1994, there was no international convention that dealt directly with peacekeeping. When the UN peace operation enjoys the consent of the state, usually a status of force agreement exists between the UN and the host state governing the protection of those involved in the UN peace operations.

The UN peace forces are part of the UN personnel and are considered representatives of the $\mathrm{UN}$ in the host state. The international community has given them significant protection and has special interest in criminalizing armed attacks on them. In particular, the Convention on the Safety of United Nations and Associated Personnel, 1994 criminalizes attacks against UN and associated personnel, as an offence, subject to universal jurisdiction. ${ }^{27}$

Four elements must be satisfied in order to criminalize the attacks against UN peace forces. (a) The attack must be directed against personnel, installations, material, units or vehicles involved in a humanitarian assistance or peacekeeping mission in accordance with the UN Charter; (b) They must be the objects of the armed attack (intention); (c) They must be entitled to the protection given to civilians or civilian objects under IHL; (d) The actor must know or have reason to know that they are protected. Traditional

${ }^{26}$ Hug Breakey, ANGus Francis, Vesselin POPOVSKI ET AL., ENHANCING PROTECTION CAPACITY: POLICY GUIDE TO THE RESPONSIBILITY TO PROTECT AND THE PROTECTION OF CIVILIANS, at 8 , available at http://isp.unu.edu/publications/files/R2P_POC_Overview_Document.p df; (last visited on Sep. 12, 2015); Kindred, Hugh M., The Protection of Peacekeepers, 33 CANADIAN YEARBOOK OF INTERNATIONAL LAW 257, 263 (1995).

27 Convention on the Safety of United Nations and Associated Personnel art 9-16, Dec. 09, 1994. 
peacekeeping operations based on Chapter VI of the UN Charter, using force only in self defence as last resort, constitute a noncombatant force. On the other hand, peace enforcement operations are based on the binding powers of the Security Council under Chapter VII and their deployment on the ground involves the use of force outside the purview of self defence. The peacekeepers are always considered as civilians and are subject to special protection from armed attacks. In contrast the peace enforcers are allowed to engage in combats and therefore are legitimate military targets. ${ }^{28}$

Over the years, peacekeeping has evolved from a primarily military model of observing ceasefires and the separation of forces after inter-state wars, to incorporate a complex mode of many elements military, police and civilians, working together to help lay the foundations for sustainable peace. ${ }^{29}$ These complex multidimensional operations (robust peacekeeping operations) demand accuracy in dealing with them, since the risk of casualties could frequently occur. However, the variety of functions among the robust peacekeeping personnel requires that a distinction also be made within the operation which is essentially of a military nature.

This risk is exemplified by the UN peace operations in the Democratic Republic of the Congo, where the staggering complexity of armed conflict obliged the Security Council to modify the traditional peacekeeping operation (MONUC) into a robust peacekeeping Operation (MONUSCO), and more recently to directly engage in offensive operations against target armed groups, in order to neutralize them by deploying a peace enforcement operation, FIB (Force Intervention Brigade). The

28 U.N. Doc. ST/SGB/1999/13, \& 1; Devon Whittle, Application of International Humanitarian Law to United Nations Forces, 46 GEORGETOWN JOURNAL OF INTERNATIONAL LAW 837, 840-41 (2015).

${ }^{29}$ United Nations Peacekeeping Operations, Principles and Guidelines, $\llbracket 18$. 
robust peacekeeping operation still remains, providing logistical support, intelligence and direct liaison on the ground. ${ }^{30}$

Intentionally directing attacks against personnel, installations, material, units or vehicles involved in humanitarian assistance or peacekeeping mission in accordance with the UN Charter is forbidden by $\mathrm{IHL}^{31}$ and is punishable under ICL ${ }^{32}$; as long as they are entitled to the protection given to civilians or civilian objects under the international law of armed conflict. This article examines the protection that needs to be afforded to the personnel of robust peacekeeping operations, while discussing their participation in hostilities.

It is important to highlight that the concept of 'civilian population' or 'civilian' according to the Geneva Conventions 1949, refers to "persons who took no active part in the hostilities, or who were no longer taking an active part in the hostilities".33 Thus civilians could be part of the population or they could be individuals who were formerly combatants. This concept functions in consonance with the concept of neutrality.

30 U.N.S.G., REP. No. S/2015/486, ๆ $19-22$ at 6-7 (2015); Magdalena Pacholska, (Il)legality of Killing Peacekeepers, The Crime of Attaching Peacekeepers in the Jurisprudence of International Criminal Tribunals, $1 \mathrm{~J}$ INT CRIMINAL Justice, 25 (2015); Devon Whittle, Application of International Humanitarian Law to United Nations Forces, 46 GEORGETOWN JOURNAL OF INTERNATIONAL LAW 837, 838-41 (2015).

31 Rule 33: Personnel and Objects Involved in a Peacekeeping Mission, International Committee of the Red Cross, https://www.icrc.org/customaryihl/eng/docs/v1_rul_rule33 (last visited on Sep. 09, 2015).

${ }^{32}$ The Rome Statute of International Criminal Court art. $8 \mathrm{~b}$ ) (iii), Statute of the Special Court of Sierra Leone, art. 4 (b).

33 Protocol Additional to the Geneva Conventions, 12 August 1949; Protection of Victims of International Armed Conflicts (Protocol I) art. 51(3), Jun. 08, 1977; Protocol Additional to the Geneva Conventions of 12 August 1949, Protection of Victims of Non-International Armed Conflicts (Protocol II) art. 13(3). 


\section{Neutrality or Impartiality of the Robust Peacekeeping Operations}

Robust peacekeeping operations are impartial. They must protect civilians at risk and certain threatened places, without taking into account who is the attacker. Though the Security Council takes part in the armed conflict when it orders coercive measures, this partisanship does not however mean taking side in favour of one of the parties of the armed conflict. Indeed the Security Council takes the side of the civilians threatened by the internal armed conflict and of the surrounding states, whose stability can also be threatened by it. In doing so, the UN may lose its neutrality (if neutrality is understood as not taking part in an armed conflict) ${ }^{34}$, but this is the result of the execution of its functions as guardian of international peace and security. Impartiality or neutrality therefore means "adherence to the principles of the Charter and to the objectives of a mandate that is rooted in those Charter principles." 35

\section{Direct Participation in Hostilities}

As stated above, robust peacekeeping includes the use of military force. ${ }^{36}$ The UN peace forces are often deployed in combat zones. They have to be prepared to defend themselves and to carry out attacks and military actions as a typically belligerent party of an armed conflict. Both, peace enforcement and robust peacekeeping operations belong to the coercive measures under Chapter VII of the UN Charter. The difference between them lies in the UN Mandate. The mandate for robust peacekeeping operations is limited to self defence activities in a broad sense, while the mandate for peace enforcement operations authorizes the use of military force (even beyond the limits of self defence in a broad

34 ELADIO ARROYO LARA, LA NO BELIGERANCIA: ANALYSIS JURIDICO 126, 146 (La Laguna ed., 1981).

35 U.N. General Assembly-Security Council, Report of the Panel on United Nations Peace Operations, A/55/305/-S/2000/809 \$50 (Aug. 21, 2000).

36 Department of Public Information, The Blue Helmets: A Review of United Nations PeaceKeEPING 350, 4 (New York United Nations, 1985); Mohamed A. Osman, The United Nations and PeACE Enforcement: WARS, TERRORISM AND DEMOCRACY 17 (Ashgate Publishing, 2002). 
sense), as far as it is necessary for the fulfilment of the UN Mission to enforce peace. Thus the latter are considered combatants and not subjects who can avail protection given to civilians under IHL. Robust peacekeeping operations on the contrary are authorized to use military force only within the limits of self defence in a broad sense and to ensure the compliance with the mandate. ${ }^{37}$

However, peace enforcement operations as well as robust peacekeeping operations occasionally are given the same tasks, which makes the latter more likely to take an active part in hostilities, increasing its risk to be susceptible to attacks. However, it needs to be analysed as to whether the offences against the personnel of robust peacekeeping operations are punishable under international law.

As observed by the Special Court of Sierra Leone (SCSL), the authorisation to use force under Chapter VII to these types of UN peace operations is limited to strictly prescribed circumstances ${ }^{38}$ and consequently they are prohibited from engaging in hostilities ${ }^{39}$ except in those foreseen situations. Thus, the fact that the UN peace forces were empowered under Chapter VII to use force in certain exceptional and restricted circumstances does not alter the

${ }^{37}$ Ademola Abbas, The United Nations, the African Union and the Darfur Crisis, 54(3) NETH. INT. LAW REV. 415, 430 (2007); Papastavridis, Interpretation of Security Council resolution under Chapter VII in the aftermath of the Iraqui Crisis, 56 ICLQ 83 (2007); Frederic L Krigis, Security Council Resolution 1441 on Iraq's Final Opportunity to Comply with Disarmament Obligations, (Nov.

10 , 2002)

http:/ / www.asil.org/insights/volume/7/issue/12/security-councilresolution-1441-iraqs-final-opportunity-comply (last visited on Aug. 19, 2015); Patrick McLaren, Settling the Score with Saddam: Resolution 1441 and Parallel Justifications for the Use of Force against Iraq, 13 DUKE JOURNAL OF COMPARATIVE AND INTERNATIONAL LAW 233 (2003); Ademola Abass, The Implementation of ECOWAS' New Protocol and Security Council Resolution 1270 in Sierra Leone: New Developments in Regional Intervention, 10 U. MIAMI INT'L\& COMP. L. REV. 177, 185-86 (2001), available at http:/ / repository.law.miami.edu/cgi/viewcontent.cgi?article=1143\&cont ext=umiclr (last visited on Aug. 19, 2015).

38 SCSL Ruf Case, ๆ 1908.

39 SCSL Ruf Case, ๆ 1917. 
fundamental nature of the robust peacekeeping operation, making it a peace enforcement operation. Instead, the reference to Chapter VII merely reinforces the right of the UN peace forces to use force in self defence in a broad sense based on the binding powers of the Security Council. ${ }^{40}$

According to IHL, the UN peace forces are entitled to the protection given to civilians only insofar as they do not take a direct part in hostilities, otherwise they become combatants and therefore legitimate military targets. The use of force in self defence which includes defending oneself, defending others, defending property does not necessarily mean taking direct part in hostilities, ${ }^{41}$ but completing other tasks under the mandate. ${ }^{42}$

The direct participation in hostilities involves "acts which by their nature or purpose, are intended to cause actual harm to the enemy personnel and material." 43 It implies a "direct causal relationship between the activity engaged in and the harm done to the enemy at the time and place where the activity takes place". It can also be proved by the carrying of weapons and the clear willingness to use them beyond self defence.44 Hence, the personnel of robust peacekeeping operation are authorized to take 'the necessary means' in order to fulfil the mandate given by the Security Council.They can therefore make use of force in a more active way rather than limiting it to resist attacks in order to defend oneself

40 SCSL Ruf Case, $\mid$ 1910-11.

${ }^{41}$ SCSL Ruf Case, $\uparrow 233$.

${ }^{42}$ J. Solan, Peacekeepers under Fire: Prosecuting the RUF for Attacks against the UN Assistance Mission in Sierra Leone, 9 THE LAW AND PRACTICE OF INTERNATIONAL COURTS AND TRIBUNAS 243, 282-84 (2010).

43 Inter-American Commission on Human Rights, Third Report on the Human Rights Situation in Colombia, OEA/Ser.L/V/II.102 Doc. 9 rev. 1, Feb. 26, 1999, ๆ 53.

${ }^{44}$ Prosecutor v Dusko Tadic [1997] I.C.T.Y. Judgement, Case No. IT-94-1T, 60 - 65.; Jean-François Quéguiner, Direct Partitipation in Hostilities under International Humanitarian Law, INTERNATIONAL COMMUNITY OF THE RED CROSS 4-6 (Sep., 2003) https://www.icrc.org/ara/assets/files/ other/ direct_participation_in_hostilities_sept_2003_eng.pdf (last visited on Sep. 09, 2015). 
and others. Thus, by taking active part in hostilities, the difference between robust peacekeeping operations and peace enforcement operations is blurred.

The SCSL also states that "in determining whether the peacekeeping personnel are entitled to civilian protection, the Chamber must consider the totality of the circumstances existing at the time of the alleged offence, including, inter alia, the relevant Security Council resolutions for the operation, the specific operational mandates, the role and practices actually adopted by the peacekeeping mission during the particular conflict, their rules of engagement and operational orders, the nature of the arms and equipment used by the peacekeeping force, the interaction between the peacekeeping force and the parties involved in the conflict, any use of force between the peacekeeping force and the parties in the conflict, the nature and frequency of such force and the conduct of the alleged victim(s) and their fellow personnel". ${ }^{45}$

Since robust peacekeeping operations are composed of different kinds of personnel with a variety of functions, another well known principle of IHL, i.e. the principle of distinction, must be taken into account in order to determine the afforded protection. ${ }^{46}$ Thus, distinction shall be made between civil, medical, police and military personnel. However only military personal involved in robust peacekeeping operations have the right to participate directly in hostilities in accordance with Chapter VII of the UN Charter.

An armed attack against robust peacekeeping forces' personnel will therefore constitute a violation of IHL, if the UN peace forces are not taking direct part in hostilities; the military members on the other hand, whose function is to continuously take a direct part in hostilities (either in self defence in a broad sense or to fulfil its mandate) are granted the rights of combatants and do not enjoy the protection given to civilians. In this line the membership

45 SCSL RUF case, $\mathbf{} 234$.

46 Magdalena Pacholska, (Il)legality of Killing Peacekeepers, The Crime of Attaching Peacekeepers in the Jurisprudence of International Criminal Tribunals, 1 INT. CRIMINAL JUSTICE JOURNAL 4, 11 (2015). 
approach $^{47}$ commonly used to qualify personnel engaged in hostilities as combatants, can also be used to qualify the robust peacekeeping military personnel as combatants. Indeed they are part of one of the armies present in the host state. As such they are inducted into a military structure, have been trained as soldiers, they have the knowledge as to when to use appropriate military force, and also the capacity to do it. They are under a command responsible for the conduct of their subordinates, are subject to an internal disciplinary system, which enforces compliance with the rules of IHL, have a fixed distinctive sign recognizable at a distance (usually blue berets) and carry arms openly. ${ }^{48}$ Therefore they never appear and conduct themselves as civilians while carrying their weapons openly and wearing uniform during their deployment in an armed conflict. 'Membership', for this purpose, would be interpreted as permanent active participation; ${ }^{49}$ that is as long as they are acting as soldiers, fulfilling a UN Mandate they are engaged from the beginning of the mission to its completion in a military deployment, distinguished thereby from the persons who sporadically participate in hostilities.

\section{Conclusion}

The UN peace forces, though not being civilians, enjoy a similar protection as long as they are not taking part in hostilities. Attacks on traditional peacekeeping operation personnel constitute a violation of IHL. Thus intentionally directing attacks against them is a punishable war crime. On the other hand UN peace enforcement operation personnel are considered as combatants and therefore a legitimate target. As regards UN robust peacekeeping operations' personnel, there is no uniform answer to the question.

\footnotetext{
47 Jann K. Kleffner, The Notions of civilians and Fighters in Non-International Armed Conflicts, Conduct of Hostilities Revisiting the Law of Armed Conflict, INTERNATIONAL INSTITUTE OF HUMANITARIAN LAW 67, 72 (Gian Luca Beruto, 2008); Nils Melzer, Direct Participation in Hostilities, I.C.R.C. 16, 334, 71 (2009).

48 Additional Protocol I art. 43 (1,2) (1977); Geneva Convention III relative to the Treatment of Prisioners of War art 4(2) (1949).

49 KLEFFNER, supra note at 47.
} 
Rather, their situation depends on their function and mandate within the robust peacekeeping operation. They are entitled to the protection given to civilians under the international law of armed conflict unless they are actively engaged as combatants.50 The military personnel of robust peacekeeping operations generally qualify as combatants.

If the military personnel engaged in robust peacekeeping operations are entitled to the same protection as civilians, they would unduly benefit from a military advantage as against the other parties to the armed conflict. The UN forces would be allowed to attack the parties to the conflict at all times, while they would be legitimate targets only during the time when they actually, directly and actively participate in hostilities; during all other times they would be entitled to protection. Such a conclusion must be categorically denied. To give the military personnel, engaged in a robust peacekeeping operation, the special civilian protection would contradict the principle of distinction. They are combatants taking a direct part in hostilities while deployed in a military operation. As such they are distinct from the civil, medical and police personnel of the operation: attacks on whom are generally forbidden unless they engage in hostilities and only for such time as they take a direct part in hostilities.

50 United Nations Convention on the Safety of United Nations and Associated Personnel arts. 7, 9, U.N. Doc, ST/SGB/1999/13 (1999). 